\title{
THE MUSKOX (Ovibos moschatus)
}

\author{
By R. Glover
}

\section{Discovery and Early History}

On 26th June, 1689, an English youth, named Henry Kelsey, and an Indian boy set out northwards on a month-long journey from a newly-founded trading post at the mouth of the Churchill River in Hudson Bay. Their object was to find Indians who might bring furs to the new post, but they hiked an estimated 200 miles out and back over the Barrens without meeting a single human being. If, however, their trip was commercially a fruitless, as well as an arduous enterprise, they still made one discovery of some scientific interest. On Sunday, 9th July, Kelsey recorded in his diary: "in $y^{e}$ Evening spyed two Buffillo left our things \& pursued $\mathrm{y}^{\mathrm{m}}$ Kill'd one they are ill shapen beast their Body being bigger than an ox leg \& foot like $\mathrm{y}^{\mathrm{e}}$ same but not half so long a [long] neck \& head a hog their Horns not growing like other Beast but joyn together upon their forehead \& so come down $y^{\text {e }}$ side of their head \& turn up till $y^{\mathbf{e}}$ points be Even $w^{\text {th }}$ ye Buts their Hair is near a foot long" (Doughty and Martin, 1929, pp. 27-8).

This is the first description by a European of that still rather slightly known Arctic beast and strange link between the families of sheep and cattle, the muskox. Kelsey's phrase "head a hog " is odd, but may make sense when it is recalled that the muskox has a somewhat sheep-like face, and that Wright's Dictionary of Dialect defines a hog as " a sheep from six-months old till being first shorn ". If, then, the word we have ventured to bracket may be regarded as a repetitious miscopying, Kelsey's description was good; but, as his very interesting diaries lay long unpublished, the first person to make the animal known was the Frenchman, Nicholas Jérémie, who published a brief, hearsay account of it in 1720 (Douglas and Wallace, 1926, pp. 19-20). A trace more information about the muskox reached the civilized world as a result of that co-operation between the Hudson's Bay Company and the Royal Society, which produced many natural history discoveries in the seventeen seventies. A skin and some skulls sent home at this time enabled Thomas Pennant to show the readers of his Arctic Zoology a fairly good engraving of what muskoxen looked like (Pennant, 1784, pl. vii). For a competent description of the animal's habits, however, scientists had to wait for the posthumous publication in $\mathbf{1 7 9 5}$ of a fine book by the explorer, 
Samuel Hearne, who had served the Hudson's Bay Company for some twenty years in North America.

\section{The Authority of Hearne}

Hearne is little known to-day, but few among all the Englishmen, who have wandered in remote parts of the earth, have been better naturalists. He had spent the best part of three yearsNovember, 1769, to June, 1772-ranging over the northland between Hudson Bay and the Arctic Ocean with various parties of Chipewyans to discover the Coppermine River. Much of the ground he covered was the then virgin territory of the muskox. He was a first-class observer of the ways of both men and beasts. He deserves greater fame, perhaps, than he enjoys as the discoverer of the woodland race of the American bison (Bison b. athabascae), of Parry's ground squirrel (Citellus parryi), and of Ross's goose (Chen rossi). His descriptions of the habits of the bison, caribou, moose, and beaver were about the earliest sound observations on these animals to reach Europe. For unbiased objectivity combined with first-hand knowledge, his account of the muskox has scarcely been superseded yet. Doubtless his remarks on the muskox contain statements that rest on the information of his Indian companions, not his own observation, but this information is by no means to be despised. As Dewey Soper $(1030$, p. 38) discovered, the primitive hunter has a knowledge of birds and beasts " which may well surprise many of our own naturalists". Indeed the primitive hunter had better have such knowledge; his livelihood depends upon it!

\section{The Habits of Muskoxen}

Hearne (1795, pp. 135-9) then stands as probably our best single authority on the habits of muskoxen. He writes that they " delight in the most stony and mountainous parts of the barren ground, and are seldom found at any great distance from the woods". Here Hearne's last remark is misleading; no doubt he saw most of his many muskoxen near the woods, but in fact the animal ranges, far to the north of the last stunted clumps of spruce and tamarack, into the treeless islands of the Arctic; all the same Hearne's remark may remain valuable as an indication of the sort of country in which the mainland muskoxen throve best in the days of their primitive abundance.

"Though they are a beast of great magnitude, and apparently of a very unwieldy inactive structure," Hearne continues of the muskoxen, "yet they climb the rocks with great ease and 
agility, and are nearly as sure-footed as a goat : like it too they will feed on anything; though they seem fondest of grass, yet in Winter, when that article cannot be had in sufficient quantity, they will eat moss or any other herbage they can find, as also the tops of willows and the tender branches of the pine tree." Later observers (Richardson, 1829, p. 277) have echoed Hearne's admiration of the agility and sure-footedness of the muskox. One recent explorer (Stefansson, 1944, p. 584) has argued that the animal has no use for moss and is almost exclusively a grasseater; but in the Thelon valley in November, 1928, W. H. B. Hoare (IIvare and Anderson, 1930, p. 20) tracked a party of muskoxen which had deliberately ignored the grass of a slope they had climbed, in order to graze the moss growing at its crest. The animal's fondness for willow twigs, and curiously of elm twigs also, has been confirmed in captivity (Jennison, 1929, p. 238).

Of the breeding habits of muskoxen, Hearne writes: "They take the bull in August and bring forth their young the latter end of May or beginning of June; and they never have more than one at a time ... In the rutting season [the bulls] are so jealous of the cows that they run at either man or beast who offers to approach them; and they have been observed to run and bellow even at ravens and other large birds, which chanced to light near them." The muskox bull's resentment even of birds approaching his cows during the rut is a striking observation, and has, I am told, been confirmed by recent travellers. It has lately been found that the gestation period is eight months rather than nine months (Young, 1942, pp. 320-1), and the rate of increase is slow. Cows do not calve till they are five years old (Young, loc. cit.), and thereafter, states G. H. D. Clarke (1940, p. 81) they calve "only in alternate years unless the calves are forcibly weaned or lost in the first year". In contradiction to Clarke, I have heard it asserted, on what would appear excellent authority, that the cows do breed annually and regularly like domestic cattle. This assertion, however, hardly seems confirmed by the published records of a herd of Greenland muskoxen kept in Alaska. From the number of thirty-two head in 1935 (Young, loc. cit.), this herd had increased only to 115 beasts in 1943 (Palmer and Rouse, 1945, p. 48)-an average increase of only some ten head per season, although the herd had contained thirteen already fully adult young cows in 1985, and more heifers must surely have matured in eight years. Again, a recent report on a wild herd on the Canadian Barrens stated that the eight young stock seen with eight cows consisted 
of three yearlings and five calves (Banfield, 1951, p. 121). The formula " one muskox calf per two adult cows per annum" is perhaps a sound enough working rule.

Muskoxen are generally gregarious. "I have frequently," writes Hearne, "seen many herds of them in the course of a day's walk and some of these herds did not contain less than eighty or a hundred head. The number of bulls is very few in proportion to the cows; for it is rare to see more than two or three full-grown bulls with the largest herd; and from the number of males that are found dead, the Indians are of opinion that they kill each other in contending for the females." These remarks on a disproportion of the sexes among muskoxen are curious and almost certainly not accurate. It may well be true, however, that the actual herds Hearne saw contained a large majority of cows, and, if so, his observation may suggest that the sexes tend, at least at some seasons, to herd scparately; a degree of support for this suggestion is to be found in the evidence of some later travellers (Pike, 1892, p. 168; Russell, 1898, p. 233 ; Hoare and Anderson, 1930, pp. 27, 33). Furthermore, the writer has been shown a recent air photograph, taken in summer, in which the camera has clearly and sharply caught forty-three galloping muskoxen, all of which seemed to have the heavy horn development of mature bulls, without apparently a female in the whole herd. That casualties are frequent in fights between bulls is possible ; the belligerence of muskoxen, even out of the rut, has attracted the notice of more than one recent observer (Tyrrell, 1908, p. 112; Hoare and Anderson, 1930, p. 27 ; Bell, 1931, p. 293).

Perhaps because his Indian companions did not make a regular habit of killing the animals, Hearne fails to describe the characteristic defensive drill of the muskox herd which has been much exploited by later hunters. Though the fact has been challenged (Clarke, 1940, p. 83), the wolf seems a real enemy to the muskox (Hanbury, 1904, p. 86), but muskoxen do not always run from wolves. Instead, they may turn to bay, and stand, horns outward, in a bunch, from which individual beasts may charge an over-adventurous aggressor (Pike, 1892, p. 104; Stefansson, 1944, p. 583). Their defence against their natural enemy thus rests upon mutual support, and therefore, though old bulls are sometimes found alone, gregariousness is probably an important factor in the animal's survival on wolfinfested Barrens. (See frontispiece.)

Hearne's last remark on the muskox (Hearne, 1795, p. 172) has been overlooked, but is important. "It is perhaps not 
generally known, even to the curious," he writes, " . . . that the dung of the muskox, though so large an animal, is not larger and at the same time so near the shape and colour of that of the Alpine hare, that the difference is not easily distinguished but by the natives." The small, pelletted dung of the muskox emphasizes his near-relationship to the sheep; had that very learned American, J. A. Allen (Allen, 1913, p. 172) known this isolated and unindexed passage in Hearne's book, he might not have argued that the muskox did not form a genus midway between the sheep and cattle, but was next-of-kin to the bison.

\section{Use of the Muskox by Natives}

In primitive times muskoxen were rather little molested by man. They were likely to defend themselves with vigour, and in 1911 the Eskimos of Coronation Gulf, whose only weapon was the bow, told R. M. Anderson (Commission, 1922, p. 76) that they might attack an old solitary bull, but usually left herds alone. The meat of full-grown males at least is often tough and tainted with musk, and the natives much preferred caribou venison (Hanbury, 1904, p. 120). The hide makes poor leather, but was occasionally used for mocassin soles (Hearne, 1795, pp. 252-3, 135). Of the long hair that dangles from the animal's throat and neck the Eskimos of old used to make "musketto wigs", to hang over their faces as a protection from the insect pests of summer (ibid., p. 137). Spoons and ladles were quarried out of the muskox's massive horn; strips of horn, boiled, straightened, and then glued together were-and sometimes still are-used by Eskimos to make bows. These are impressively powerful weapons to handle.

\section{Hunting By Sportsmen}

Toward the end of the last century, and in the first decade of this, a very few English and American sportsmen went to the Barrens to hunt muskoxen. Apart from the hardship involved, the sport had little to commend it. Muskoxen, when disturbed, may bolt, in which case they will "leave for another part of the country. It is hopeless to follow them ", wrote one sportsman (Hanbury, 1904, p. 87). Alternatively they may bunch and turn to bay against the hunter's sled dogs, as they would against wolves; in that case, the sport of muskox hunting is hardly more exciting than shooting down a flock of penned sheep, as another disappointed sportsman wrote (Russell, 1898, p. 124). 


\section{Commercial Exploitation}

By and large, then, there has been little reason for the muskox to suffer at the hands of men, except during one short period when he was intensely persecuted. Before the coming of the motor car, the horse and sleigh was a normal means of family transport in those parts of America which were snow-bound in winter ; and mighty cold one could get, gliding over the snow in an open sleigh, when temperatures were low and winds keen. It was for this reason that warm and cosy "buffalo robes" were in such demand while the bison lasted on the great plains. When the bison were gone, the still warmer and woollier muskox robes became very desirable in Canada and the United States. Then the Indians found it worth their while to hunt far out on the Barrens for skins they sold at Fort Rae and Fort Resolution. The Eskimos also sold many skins to the whalers who, before and after the turn of this century, frequented Hudson Bay and the western Arctic in some numbers.

Once the natives had firearms the killing of muskoxen was easy and the slaughter was great; "I have seen muskox robes stacked by the Eskimos like haycocks along the shore of Chesterfield Inlet, awaiting an opportunity to market them," writes one witness (Tyrrell, 1908, p. 241). Before this onslaught the mainland muskoxen withered away from most stretches of the Barrens within easy reach of the coast or of the Great Slave Lake. Among the Arctic islands the muskoxen of Banks Island were early exterminated ; the last on Victoria Island lingered perhaps till the 1920's (Hoare and Anderson, 1930, p. 47), but a well-informed friend of the writer believes none remain there to-day.

\section{Destruction By Explorers}

Dr. R. M. Anderson (Hoare and Anderson, 1930, p. 49) lists explorers as another hazard to the muskox. That he has reason for doing so is apparent from Dr. Stefansson's statement (Stefansson, 1944, p. 588) : "In Melville Island we killed entire herds whenever we needed them," and Stefansson's assistant, Storker Storkerson, reported killing in one season 400 muskoxen on Melville Island, a figure he estimated to amount to 10 per cent of the island's total muskox population (Commission, 1922, p. 15).

\section{Present Situation}

Yet, thanks to the remoteness of its haunts, the muskox survived its persecution, without ever coming really near to 
extinction, and present-day conditions seem favourable to it. The closed car, with its heater, has destroyed the once great market for robes; explorations are now commonly supplied by air ; in Canada at least protective regulations are generally rigid; and the lands the animal inhabits are but thinly, if at all, populated by men. For the last reason it is also far from easy to assess the muskox's present status. It is extinct in most of Greenland, but an English friend has told the writer that he found the animal not uncommon in the north-eastern parts of that great island in the late 1930's.

In Alaska the muskox survived till late in the nineteenth century, as is attested by the discovery of skulls and by recent Eskimo tradition. In 1930 the U.S. Department of Agriculture decided to reintroduce the animal there, and acquired the necessary stock by engaging a Norwegian sea captain to catch youngsters in N.E. Greenland. In the result the Department received thirty-four young muskoxen, which were taken after the mature animals with which they ran had been shot (Bell, 1931, p. 293). The animals were kept in large pasture at Fairbanks, Alaska, till they began breeding. Then the herd was transported to Nunivak Island, which lies 25 miles off the mouth of the Yukon River. This island has nearly a million acres of grazing and is free of bears and wolves. The increase of the herd to 115 head by 1943 has been noted, but thereafter (if what one hears is correct) the local Eskimos started shooting muskoxen and the herd declined drastically. Another unfortunate circumstance on Nunivak Island is the fact that the pasture has been heavily overgrazed by semi-domestic reindeer and has deteriorated badly. The reduction of the reindeer has been begun, however, and the U.S. government's aims for the future are perhaps expressed in an official publication, which states (Palmer and Rouse, 1945, p. 48) : "On the basis of forage acres, the range capacity of Nunivak Island should carry 2,100 muskoxen and 8,000 reindeer." Great pains have been taken in the forage studies on which this calculation is based; one may hope that equal pains are now being taken to protect the muskoxen so that they may increase to the figure named.

In the Arctic islands of Canada the muskox has never been recorded from Ungava, Baffin Island, or the islands in the mouth of Hudson Bay. But Ellesmere Island, Axel Heiberg Island, Devon Island, Bathurst Island, Prince of Wales Island, Cornwallis Island, and Melville Island, all had healthy muskox populations in 1929, whose total Dr. R. M. Anderson (Hoare and Anderson, 1930, pp. 47, 48, 51) then estimated to exceed 12,000. 
As there are no human beings on any of these islands, except the personnel of an occasional Royal Canadian Mounted Police post or government weather station, the situation is unlikely to have changed. One rather well-known herd is commonly seen grazing near the Craig Harbour police post on Ellesmere Island. The muskoxen of Melville Island in the western Arctic have been found identical with those of Greenland, as have those of Ellesmere Island in the east, and the animals of the intervening islands are also of this race, Ovibos moschatus wardi (Lydekker). Though the fact has been denied (Stefansson, 1944, pp. 521-2), there is evidence that the animals do sometimes cross from island to island over the sea ice in winter (Hoare and Anderson, 1930, p. 47).

The muskoxen of the mainland of Canada have been split into two races, one western, one north-eastern. The first is the typical race, Ovibos moschatus moschatus (Zimmerman), to which the great majority of surviving mainland muskoxen probably belong. The second, Ovibos moschatus niphoecus (Elliot), has been described from specimens taken at Wager Inlet, and its range and the points at which it intergraded with moschatus are unknown. The mainland muskoxen have two principal strongholds to-day. One is the Thelon Game Sanctuary. The Thelon valley was first explored by the Englishman, David Hanbury, who (Hanbury, 1904, p. 13) described it as "one spot in this Great Barren Northland, which is sacred to the muskox". It lay too far east to be troubled by the Indians who brought their furs to the traders at Great Slave Lake, and too far west for the Eskimos who traded their catch along the shores of Hudson Bay. Here, then, geography protected the muskox, and geography was legally reinforced in 1927 by an Order in Council setting aside 15,000 square miles as a game sanctuary. No warden service was instituted, nor perhaps was it either practicable or necessary; instead periodic surveys have been made by biologists. The first was by W. H. B. Hoare in 1928, who counted 126 muskoxen on his trip through the valley; ninety-three of these 126 animals were seen at the same time. In 1939 C. H. D. Clarke made another survey and reported all well. Recently an air survey, made in winter, resulted in an actual count of ninety animals, which were seen on high and windswept ground, not down in the willow brush by the river, where Hoare and Clarke had found most of them in summer (Banfield, 1951, pp. 120-1).

The second mainland stronghold of the muskox lies on the Arctic coast, from Bathurst Inlet westward to the Tree River. 
Here Mr. A. W. F. Banfield reckons their numbers at some 200, but his estimate seems conservative. Banfield records a number of counts, made at points too widely dispersed for duplication to be likely, and these counts total 143 individual animals, or 75 per cent of his total estimate for the whole area. It is hard to believe that 75 per cent of the whole muskox population of any broad stretch of country could be counted under the actual line of flight of such aircraft as happened to cross it, and this particular stretch of country is notably rough and broken. From another and trusted source I have heard this area's muskoxen estimated at 500, which may well be nearer the mark. One gathers that in this Bathurst Inlet country the Eskimos still occasionally kill muskoxen. This is technically illegal, but probably inevitable. The Eskimo is a primitive hunter, who has to support himself, his family and his dogs, in a land that produces no other food than meat and fish; he cannot be legally compelled to starve on occasions when he meets muskoxen, and can find no other game ; moreover, he needs muskox horn for making bows, which are not yet obsolete in this particular part of the Arctic.

Outside of these two principal strongholds Banfield lists a pleasing number of muskoxen seen from the air-at Aylmer Lake, north-west of the sanctuary, and at Consul River and Wharton Lake, north-east and east of it respectively. Perhaps the most notable of his records is a count of 50 on the Simpson Peninsula ; these last are likely to belong to the race niphoecus.

It may be concluded, then, that the muskox has disappeared from wide areas it once inhabited. Nevertheless, very adequate stocks remain; these are well dispersed and, at least while present conditions continue, their prospects seem good. The main threat the future seems to hold for the muskox, and all other Arctic game, is the increase of the native human population, which obviously cannot be regretted and may be expected to quicken as the Canadian government's current programme of expanding its Arctic medical services brings results. The prospect of the empty Aretic islands becoming populated, however, would still seem decidedly remote.

\section{Domestication of the Muskox}

A final matter, that is currently attracting some attention in North America, is the prospect of domesticating the muskox. The idea is interesting and the animal's temperament is alleged to be suitable. Nevertheless, the proposal raises some large questions :- 
First, what measure of hardihood could be expected of the muskox in domestic conditions outside his native range? In the homeland of the muskox summer lasts for three months at most; at all other seasons frost and snow must prevent the development of the ova and larvae of helminths. Removing muskoxen to more southern climates would therefore mean exposing them to a degree of parasitic attack that they have never been required to resist, while their near relationship to domestic sheep and cattle makes it highly likely that the parasites of both these animals would thrive equally well inside them. It is then very far from certain that muskoxen could live at all on the pastures of Vermont where it is hoped to keep them; and it may be significant that (if my information is correct) four young muskoxen successfully raised in a dry yard in New York died after being transferred to a grassy enclosure.

But a still more fundamental question is, what advantage may be expected of domesticating the muskox ? Stefansson (1944, pp. 586-7) speaks well of the quality of its milk but fails to say what quantities may be expected, or what is the length of the animal's lactation. As to the beef of muskoxen, Stefansson (1944, p. 583) declares the flesh of grown males to be often very tough and others have attested that it often has a repellent taste. The meat of heifers and young animals is indeed said to be excellent; but one may doubt the economic prospects of a beef industry that depended on the slaughter of half-grown beasts and the prospective mothers of the race, because mature and surplus males were unmarketable. The evidence of late maturity and slow increase seems equally discouraging. Finally, muskox wool has been praised (Stefansson, 1944, p. 587), but unfortunately the animal's top-coat of long hair makes it impossible to shear him. Dr. Hornaday, to be sure, has told how in the Bronx Zoo the whole fleece of a muskox was once harvested by combing him; but the operation was "long and tedious", and the animal concerned died of pneumonia within a month of the job's completion (Commission, 1922 , p. 54)! Alternatively it has been suggested that the wool might be harvested by collecting it off the bushes and rocks on which the muskox rubs it during his annual moult. But here one must consider the time likely to be consumed in this weary process of, literally, "wool-gathering," and balance it against the facts that a top-class Australian shearer can clip up to 100 sheep in an eight-hour day, and that the sheep can survive the operation. If we weigh these facts, we may well dread the cost 
of our clothes in the day when the marketing of muskox wool becomes economic ! All in all, it is probably a sound conclusion that the best way of making the muskox serviceable to mankind is not by domestication, but by intelligent game management in his native home, where the annual product of his herds may support a limited number of men and their indispensable sled dogs.

\section{REFERENCES}

Allen, J. A., 1913. Ontogenetic and other Variations in Muskoxen, with a systematic review of the Muskox Group, recent and extinct. Mem. Amer. Mus. Nat. Hist., n.s. 1, part 4.

Banfield, A. W. F., 1951. Notes on Mammals of the MacKenzie District, North-West Territories. Arctic, Sept., 1951, 113-121.

Bell, W. B., 1931. Experiments in the re-establishment of the Muskox in Alaska. Journ. Mammal., vol. 12, 292-7.

Clarke, C. H. D., 1940. A Biological Investigation of the Thelon Game Sanctuary. Bull. Nat. Mus. Canada, No. 96. Ottawa: Dept. of Mines and Resources.

Commission, 1922. Report of the Royal Commission upon the Possibilities of Reindeer and Muskox Industries in the Aretic and Sub-arctic Regions. Ottawa : Dept. of the Interior.

Douglas, R., and Wallace, J. N., 1926. Twenty Years of York Factory: Jérémie's Account of Hudson Strait and Bay. Ottawa.

Doughty, A., and Martin, C., 1929. The Kelsey Journals. Ottawa.

Hanbury, D., 1904. Sport and Travel in the Northland of Canada. New York.

Hearne, S., 1795. A Journey from Prince of Wales's Fort in Hudson's Bay to the Arctic Ocean. London.

Hoare, W. H. B., and Anderson, R. M., 1930. Conserving Canada's Muskoxen. Ottawa : Dept. of the Interior.

Jennison, G., 1929. Natural History-Animals-an Illustrated Who's Who of the Animal World. London.

Palmer, L. J., and Rouse, C. H., 1945. Study of the Alaska Tundra with Reference to its Reactions to Reindeer and other Grazing. Washington : Dept. of the Interior.

Pennant, T., 1784. Arctic Zoology. London.

Pike, W., 1892. The Barren Ground of Northern Canada. London.

Richardson, John, 1829. Fauna Boreali-Americana. London.

Russell, F., 1898. Exploration in the Far North. Des Moines.

Soper, J. D., 1930. The Blue Goose. Ottawa : Dept. of the Interior.

Stefansson, V., 1944. The Friendly Arctic. New York.

Tyrreld, J. W., 1908. Across the Sub-arctics of Canada. Toronto.

Young, S. P., 1942. The Return of the Muskox. Ann. Rept. Smithsonian Inst., $1942,317-322$. 